\title{
Exploitation of sweet lemon residues in the production of essential oils
}

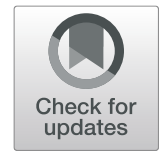

\author{
Khalid A. Khalid ${ }^{1 *}$, Ahmed E. El-Gohary ${ }^{1}$ and Aisha M. A. Ahmed ${ }^{2}$
}

\begin{abstract}
Background and objective: The constituents of sweet lemon essential oil (EO) have different biological and medical properties. The exploitation of sweet lemon residues in the production of EO is an important means of increasing natural products and disposing of those residues. The aim of this study was to evaluate the EO extracted from various sweet lemon residues such as leaves, flowers, and peels of fruits to find out their content of active substances.

Materials and methods: The EO of different residues of sweet lemon was isolated by hydrodistillation (HD) method, then they were analyzed by GC/MS. Data were statistically analyzed using ANOVA-1.

Results: The content of EO (\%) was higher in peels than in flowers or leaves. Citronellal, nerol, and limonene were the major constituents of EO extracted from leaves, flowers, and peels, respectively. All detected components of various oils belonged to four chemical fractions (monoterpene hydrocarbons $(\mathrm{MH})$, oxygenated monoterpenes $(\mathrm{OM})$ ), sesquiterpene hydrocarbons (SH), and oxygenated sesquiterpenes (OS)). The MH was the major faction of peel EO while the OM was the major fraction of leaf and flower EOs. The SH and OS were formed as the minor fractions in all EOs.
\end{abstract}

Conclusion: Different variations were observed in sweet lemon EO extracted from various residues which lead to diversity in natural sources of EO production.

Keywords: Sweet lemon, Essential oil, Leaves, Flowers, Peels, Citronellal, Nerol and limonene

\section{Background}

Essential oils are secondary metabolites formed in aromatic plants. They are volatile, terpenoids, and usually isolated by distillation methods. They have odor and several pharmaceutical, medical, and biological properties such as antiseptic, bactericidal, virucidal, and fungicidal, as well as against liver and lung carcinogenesis, colon tumors, and gastric cancer (Davis 1982; Yeung 1999; Khursheed et al. 2016). The Administration of Food and Drug (FDA) indicated that $\mathrm{EO}$ of citrus is safe natural product, so it can be added to canned food and cosmetics to prevent the propagation of pathogens and spoiling microorganisms (Fisher and Phillips 2006; Nannapaneni et al. 2009; Velázquez-Nuñez et al. 2013). The residues of different organs of citrus tree such as peels, leaves, and flowers that are produced after juice extraction, pruning of branches and change to precipitation flowers are very important sources of EO (Viuda-Martos et al. 2009), as well as citrus residues which

\footnotetext{
* Correspondence: ahmed490@gmail.com

${ }^{1}$ Medicinal and Aromatic Plants Department, National Research Centre, Dokki, Cairo, Egypt

Full list of author information is available at the end of the article
}

can serve as raw material for the extraction of EOs needed for various domestic and industrial uses (Giwa et al. 2018). Sweet lemon (Citrus limettioides Tan.), one of the citrus species, belongs to family Rutaceae. Just one literature was carried out in México to isolate and characterize the constituents of sweet lemon EO that was isolated from peels and leaves (Pino et al. 2010); this study reported that different variations were observed in the chemical constituents due to the differences in plant organs, and the major component of peel EO was limonene while the main constituents of leaf EO were limonene, citronellal, and linalool.

The yield and chemical constituents of EO can be changed by various conditions such as fertilizers, irrigation, climate, location, plant organ, and others (Krayni et al. 2015). The highest yield of EO and major constituents (thymol and carvacrol) of thyme were detected in the EO isolated from the aerial parts during the flowering stage (Jordan et al. 2006; Nejad-Ebrahimi et al. 2008; Omidbaigi et al. 2010). Different changes were recorded in the composition of oregano (Origanum onites) EO due to various plant organs (Kizil et al. 2008). The EO extracted from 
Eucalyptus cinerea fruits produced higher amount of 1,8cineole $(81 \%)$ than that isolated from leaves $(75 \%)$ and flowers (78.8\%) (Silva et al. 2011). The EO of Sodom apple extracted from the leaf, stem, flower, and fruit was analyzed by GC/MS (Wahba and Khalid 2018); leaf EO resulted in the highest values of $E$-phytol, myristicin, myristic acid, oxygenated sesquiterpenes (OS), and oxygenated diterpenes (OD); fruit EO recorded the greatest amounts of $E, E$-farnesyl acetone, monoterpene hydrocarbons $(\mathrm{MH})$, oxygenated monoterpenes $(\mathrm{OM})$, and sesquiterpenes hydrocarbons (SH). The EO components of Sarcopoterium plants were evaluated by Sipahi et al. (2017); the major components of EO isolated from the stem were aldehydes (40\%), aromatic constituents (34.0\%), and OM (21\%); aldehyde component (43\%), OS (26\%), and aliphatic hydrocarbons (21\%) were detected as the main components in leaf $\mathrm{EO}$, while aldehydes $(52 \%)$ and aromatic components (48.4\%) were identified as the main constituents of root EO.

There are no investigations on the EO composition of sweet lemon extracted from various part residues (leaves, flowers, peels) in Egypt, so the aim of this study was to describe the composition of sweet lemon EO extracted from different residues. This study may increase the sources of natural products (EO) used in food and drug industries.

\section{Materials and methods}

\section{Plant materials}

Plant materials (leaves, flowers, and peels) were collected from the citrus farm of National Research Centre (NRC) during 2 years (2017 and 2018). The citrus farm is located at the reclaimed zone and is characterized by sandy soil. The leaves were obtained from pruning trees which were collected in February. Flowers produced from the precipitation were collected in June while fruit peels were collected in November at both seasons.

\section{EO isolation}

The fresh plant materials were collected, and then $250 \mathrm{~g}$ from each replicate (three replicates) were subjected to hydrodistillation (HD) for $3 \mathrm{~h}$ using a Clevenger-type apparatus (Clevenger 1928).

\section{Gas chromatography (GC) and gas chromatography-mass spectrometry (GC-MS) conditions}

Gas chromatography analyses were performed using a Shimadzu GC-9 gas chromatograph equipped with a DB5 (dimethylsiloxane, $5 \%$ phenyl) fused silica column (J\&W Scientific Corporation) ( $30 \mathrm{~m}$ x $0.25 \mathrm{~mm}$ i.d., film thickness $0.25 \mu \mathrm{m})$. Oven temperature was held at $50^{\circ} \mathrm{C}$ for $5 \mathrm{~min}$ and then programmed to rise to $240^{\circ} \mathrm{C}$ at a rate of $3{ }^{\circ} \mathrm{C} /$ min. The flame ionization detector (FID) temperature was $265^{\circ} \mathrm{C}$, and the injector temperature was $250^{\circ} \mathrm{C}$. Helium was used as the carrier gas with a linear velocity of $32 \mathrm{~cm} / \mathrm{s}$.
The percentages of compounds were calculated by the area normalization method, without considering response factors. GC-MS analyses were carried out in a Varian 3400 GC-MS system equipped with a DB-5 fused silica column $(30 \mathrm{~m} \times 0.25 \mathrm{~mm}$ i.d., film thickness $0.25 \mathrm{~lm}$ ); the oven temperature was $50-240^{\circ} \mathrm{C}$ at a rate of $4{ }^{\circ} \mathrm{C} / \mathrm{min}$, transfer line temperature $260^{\circ} \mathrm{C}$, carrier gas, helium, with a linear velocity of $31.5 \mathrm{~cm} / \mathrm{s}$, split ratio 1:60, ionization energy $70 \mathrm{eV}$, scan time $1 \mathrm{~s}$, and mass range 40-300 amu.

\section{Identification of volatile components}

The components of EOs were identified by comparison of their mass spectra with those of a computer library or with authentic compounds and confirmed by comparison of their retention indices (RI), either with those of authentic compounds or with data published in the literature (Adams 1995). Mass spectra from the literature were also compared (Adams 1995). Further identification was made by comparison of their mass spectra on both columns with those stored in NIST-98 and Wiley-5 Libraries.

\section{Statistical analysis}

In this experiment, one factor was considered: plant part residues (leaves, flowers, and peels). For each residue, there were three replicates; the experimental design followed a complete random block design. The average data of both seasons were statistically analyzed using one-way analysis of variance, ANOVA-1 (Snedecor and Cochran 1990). Significant values were determined according to $P$ values $(P<0.05=$ significant and $P<0.01=$ highly significant). The applications of that technique were according to the STATITCF program version 7 (Foucart 1982).

\section{Results}

EO content

Different variations are detected in sweet lemon EO (\%) with various plant part residues (leaves, flowers, and peels) (Table 1). The greatest EO percentage is found in

Table 1 Changes in EO contents and chemical fractions of various plant residues

\begin{tabular}{|c|c|c|c|c|c|c|c|}
\hline \multirow[t]{2}{*}{ EO composition } & \multicolumn{2}{|c|}{ Leaves } & \multicolumn{2}{|c|}{ Flowers } & \multicolumn{2}{|l|}{ Peels } & \multirow[t]{2}{*}{$F$ values } \\
\hline & Mean & SD & Mean & SD & Mean & SD & \\
\hline Total EO (\%) & 0.2 & \pm 0.1 & 0.1 & \pm 0.0 & 0.3 & \pm 0.1 & $4.5^{*}$ \\
\hline \multicolumn{8}{|c|}{ Total chemical fractions } \\
\hline $\mathrm{MH}$ & 24.9 & \pm 0.0 & 24.7 & \pm 0.3 & 79.6 & \pm 0.4 & $34,650.8^{* *}$ \\
\hline $\mathrm{OM}$ & 71.1 & \pm 0.1 & 61.4 & \pm 0.4 & 12.2 & \pm 0.2 & $42,742.4^{* *}$ \\
\hline $\mathrm{SH}$ & 1.6 & \pm 0.3 & 1.8 & \pm 0.2 & 4.3 & \pm 0.3 & $70.2^{* *}$ \\
\hline OS & 1.7 & \pm 0.4 & 11.4 & \pm 0.4 & 3.3 & \pm 0.3 & $715.9^{* *}$ \\
\hline Total identified & 99.3 & & 99.3 & & 99.4 & & \\
\hline
\end{tabular}

Note: ${ }^{*} P<0.05=$ significant; ${ }^{* *} P<0.01=$ highly significant. Values are given as Mean $\pm \mathrm{SD}$ 
Table 2 Changes in EO constituents of various plant residues

\begin{tabular}{|c|c|c|c|c|c|c|c|c|c|c|}
\hline \multirow[t]{2}{*}{ No } & \multirow[t]{2}{*}{ EO constituents (\%) } & \multirow[t]{2}{*}{ RI } & \multirow[t]{2}{*}{ Fractions } & \multicolumn{2}{|c|}{ Leaves } & \multicolumn{2}{|c|}{ Flowers } & \multicolumn{2}{|l|}{ Peels } & \multirow[t]{2}{*}{$F$ values } \\
\hline & & & & Mean & SD & Mean & SD & Mean & SD & \\
\hline 1 & a-Thujene & 931 & $\mathrm{MH}$ & 0.3 & \pm 0.1 & 0.1 & \pm 0.0 & 1.1 & \pm 0.1 & $126.1^{* *}$ \\
\hline 2 & a-Pinene & 939 & $\mathrm{MH}$ & 0.4 & \pm 0.1 & 1.6 & \pm 0.2 & 0.2 & \pm 0.1 & $86.1^{* *}$ \\
\hline 3 & Camphene & 953 & $\mathrm{MH}$ & 0.4 & \pm 0.1 & 0.1 & \pm 0.0 & 0.1 & \pm 0.0 & $27.0^{* *}$ \\
\hline 4 & Sabinene & 976 & $\mathrm{MH}$ & 0.5 & \pm 0.1 & 0.6 & \pm 0.1 & 1.8 & \pm 0.2 & $78.5^{* *}$ \\
\hline 5 & $\beta$-Pinene & 980 & $\mathrm{MH}$ & 0.3 & \pm 0.1 & 1.6 & \pm 0.2 & 0.3 & \pm 0.1 & $112.5^{* *}$ \\
\hline 6 & Myrcene & 991 & $\mathrm{MH}$ & 3.8 & \pm 0.2 & 2.8 & \pm 0.2 & 0.7 & \pm 0.2 & $187.8^{* *}$ \\
\hline 7 & a-Phellandrene & 1005 & $\mathrm{MH}$ & 0.3 & \pm 0.2 & 0.1 & \pm 0.0 & 0.7 & \pm 0.2 & $9.9^{* *}$ \\
\hline 8 & $\Delta$-3-carene & 1011 & $\mathrm{MH}$ & 0.2 & \pm 0.1 & 1.4 & \pm 0.4 & 0.4 & \pm 0.1 & $20.7^{* *}$ \\
\hline 9 & a-Terpinene & 1018 & $\mathrm{MH}$ & 0.2 & \pm 0.1 & 1.4 & \pm 0.4 & 0.1 & \pm 0.0 & $27.7^{* *}$ \\
\hline 10 & p-Cymene & 1026 & $\mathrm{MH}$ & 0.3 & \pm 0.1 & 0.4 & \pm 0.1 & 0.1 & \pm 0.0 & $22.8^{* *}$ \\
\hline 11 & Limonene & 1031 & $\mathrm{MH}$ & 13.8 & \pm 0.2 & 12.5 & \pm 0.5 & 72.5 & \pm 0.5 & $19,576.1^{* *}$ \\
\hline 12 & Cis- $\beta$-Ocimene & 1040 & $\mathrm{MH}$ & 3.7 & \pm 0.3 & 0.6 & \pm 0.1 & 0.3 & \pm 0.1 & $289.9^{* *}$ \\
\hline 13 & Y-Terpinene & 1062 & $\mathrm{MH}$ & 0.4 & \pm 0.1 & 0.9 & \pm 0.1 & 0.7 & \pm 0.2 & $14.1^{* *}$ \\
\hline 14 & a-Terpinolene & 1088 & $\mathrm{MH}$ & 0.3 & \pm 0.1 & 0.6 & \pm 0.1 & 0.6 & \pm 0.1 & $9.1^{*}$ \\
\hline 15 & Cis-Sabinene hydrate & 1097 & $\mathrm{OM}$ & 0.5 & \pm 0.1 & 0.9 & \pm 0.1 & 0.1 & \pm 0.0 & $72.0^{* *}$ \\
\hline 16 & Linalool & 1098 & $\mathrm{OM}$ & 11.1 & \pm 0.1 & 0.8 & \pm 0.2 & 1.6 & \pm 0.1 & $4924.5^{* *}$ \\
\hline 17 & Isopulegol & 1145 & $\mathrm{OM}$ & 0.1 & \pm 0.0 & 0.1 & \pm 0.0 & 0.2 & \pm 0.1 & $3.0^{\mathrm{ns}}$ \\
\hline 18 & Citronellal & 1153 & $\mathrm{OM}$ & 51.1 & \pm 0.1 & 0.2 & \pm 0.1 & 1.9 & \pm 0.1 & $250,717.0^{* *}$ \\
\hline 19 & Terpinen-4-ol & 1177 & $\mathrm{OM}$ & 0.3 & \pm 0.1 & 0.1 & \pm 0.0 & 0.3 & \pm 0.1 & $6.1^{\mathrm{ns}}$ \\
\hline 20 & a-Terpineol & 1189 & $\mathrm{OM}$ & 0.4 & \pm 0.1 & 0.4 & \pm 0.1 & 1.1 & \pm 0.1 & $49.1^{* *}$ \\
\hline 21 & Decanal & 1204 & $\mathrm{OM}$ & 0.1 & \pm 0.0 & 0.1 & \pm 0.0 & 0.1 & \pm 0.0 & $5.2^{\mathrm{ns}}$ \\
\hline 22 & Citronellol & 1228 & $\mathrm{OM}$ & 4.9 & \pm 0.1 & 0.4 & \pm 0.1 & 2.1 & \pm 0.1 & $1549.0^{* *}$ \\
\hline 23 & Nerol & 1228 & $\mathrm{OM}$ & 0.4 & \pm 0.1 & 53.9 & \pm 0.1 & 0.1 & \pm 0.0 & $431,758.5^{* *}$ \\
\hline 24 & Cis-Carveol & 1229 & $\mathrm{OM}$ & 0.2 & \pm 0.1 & 0.1 & \pm 0.0 & 0.1 & \pm 0.0 & $3.0^{\mathrm{ns}}$ \\
\hline 25 & Citral & 1240 & $\mathrm{OM}$ & 0.1 & \pm 0.0 & 1.1 & \pm 0.1 & 1.2 & \pm 0.2 & $66.6^{* *}$ \\
\hline 26 & Geranial & 1270 & $\mathrm{OM}$ & 0.3 & \pm 0.1 & 1.6 & \pm 0.4 & 0.6 & \pm 0.2 & $19.9^{* *}$ \\
\hline 27 & Thymol & 1290 & $\mathrm{OM}$ & 0.4 & \pm 0.1 & 0.5 & \pm 0.1 & 0.8 & \pm 0.2 & $6.5^{*}$ \\
\hline 28 & Cis-Limonene oxide & 1294 & $\mathrm{OM}$ & 0.4 & \pm 0.1 & 0.1 & \pm 0.0 & 0.9 & \pm 0.1 & $73.5^{* *}$ \\
\hline 29 & Citronellyl acetate & 1354 & $\mathrm{OM}$ & 0.1 & \pm 0.0 & 0.1 & \pm 0.0 & 0.1 & \pm 0.0 & $5.2^{\mathrm{ns}}$ \\
\hline 30 & Neryl acetate & 1365 & $\mathrm{OM}$ & 0.2 & \pm 0.1 & 0.1 & \pm 0.0 & 0.1 & \pm 0.0 & $3.0^{\text {ns }}$ \\
\hline 31 & Geranyl acetate & 1383 & $\mathrm{OM}$ & 0.5 & \pm 0.1 & 0.9 & \pm 0.1 & 0.9 & \pm 0.1 & $16.0^{* *}$ \\
\hline 32 & $\beta$-Humulene & 1440 & $\mathrm{SH}$ & 0.3 & \pm 0.1 & 0.1 & \pm 0.1 & 0.3 & \pm 0.1 & $36.0^{* *}$ \\
\hline 33 & a-Caryophyllene & 1454 & $\mathrm{SH}$ & 0.3 & \pm 0.1 & 0.6 & \pm 0.1 & 0.8 & \pm 0.2 & $9.5^{* *}$ \\
\hline 34 & $\beta$-Selinene & 1485 & $\mathrm{SH}$ & 0.2 & \pm 0.1 & 0.4 & \pm 0.1 & 1.1 & \pm 0.1 & $67.0^{* *}$ \\
\hline 35 & Germacrene D & 1490 & $\mathrm{SH}$ & 0.5 & \pm 0.1 & 0.4 & \pm 0.1 & 0.4 & \pm 0.1 & $1.0^{\mathrm{ns}}$ \\
\hline 36 & $\beta$-Bisabolene & 1509 & $\mathrm{SH}$ & 0.3 & \pm 0.1 & 0.3 & \pm 0.1 & 1.7 & \pm 0.3 & $53.5^{* *}$ \\
\hline 37 & $\beta$-Nerolidol & 1546 & OS & 0.3 & \pm 0.1 & 10.3 & \pm 0.3 & 0.1 & \pm 0.0 & $3061.2^{* *}$ \\
\hline 38 & Spathulenol & 1576 & OS & 0.4 & \pm 0.1 & 0.1 & \pm 0.0 & 0.1 & \pm 0.0 & $27.0^{* *}$ \\
\hline 39 & Caryophyllene oxide & 1581 & OS & 0.5 & \pm 0.1 & 0.2 & \pm 0.1 & 1.8 & \pm 0.4 & $20.4^{* *}$ \\
\hline 40 & a-Eudesmol & 1652 & OS & 0.2 & \pm 0.1 & 0.3 & \pm 0.1 & 0.6 & \pm 0.1 & $13.0^{* *}$ \\
\hline 41 & a-Bisabolol & 1683 & OS & 0.2 & \pm 0.1 & 0.4 & \pm 0.1 & 0.5 & \pm 0.1 & $7.0^{*}$ \\
\hline 42 & È,È-Farnesol & 1722 & OS & 0.1 & \pm 0.0 & 0.1 & \pm 0.0 & 0.2 & \pm 0.1 & $3.0^{\mathrm{ns}}$ \\
\hline
\end{tabular}


peel EO (0.3\%) followed by leaf EO (0.2\%) and flower EO (0.1\%). The changes in EO oil contents are significant $(P<0.05)$ for different plant residues (Table 1$)$.

\section{EO constituents}

In this study, 42 components are observed by GC/MS analysis (range from 99.3 to $99.4 \%$ ) in leaf, flower, and peel EOs of sweet lemon trees (Table 2). Different changes are found in various constituents due to the differences in plant part residues. The major constituents of leaf EO are citronellal (51.1\%), limonene (13.8), and linalool (11.1\%). Nerol (53.9\%), limonene (12.5\%), and $\beta$ nerolidol (10.3\%) are identified as the major components in flower EO while limonene $(72.5 \%)$ is the major component in peel EO. All detected components are grouped into four chemical fractions $\mathrm{MH}, \mathrm{OM}, \mathrm{SH}$, and OS) (Table 1 and Figs. 1, 2, 3, and 4). The $\mathrm{MH}$ is the major fraction of peel EO while the $\mathrm{OM}$ is the major fraction of leaf and flower EOs. The $\mathrm{SH}$ and $\mathrm{OS}$ are formed as the minor fractions in all EOs (Table 1). The

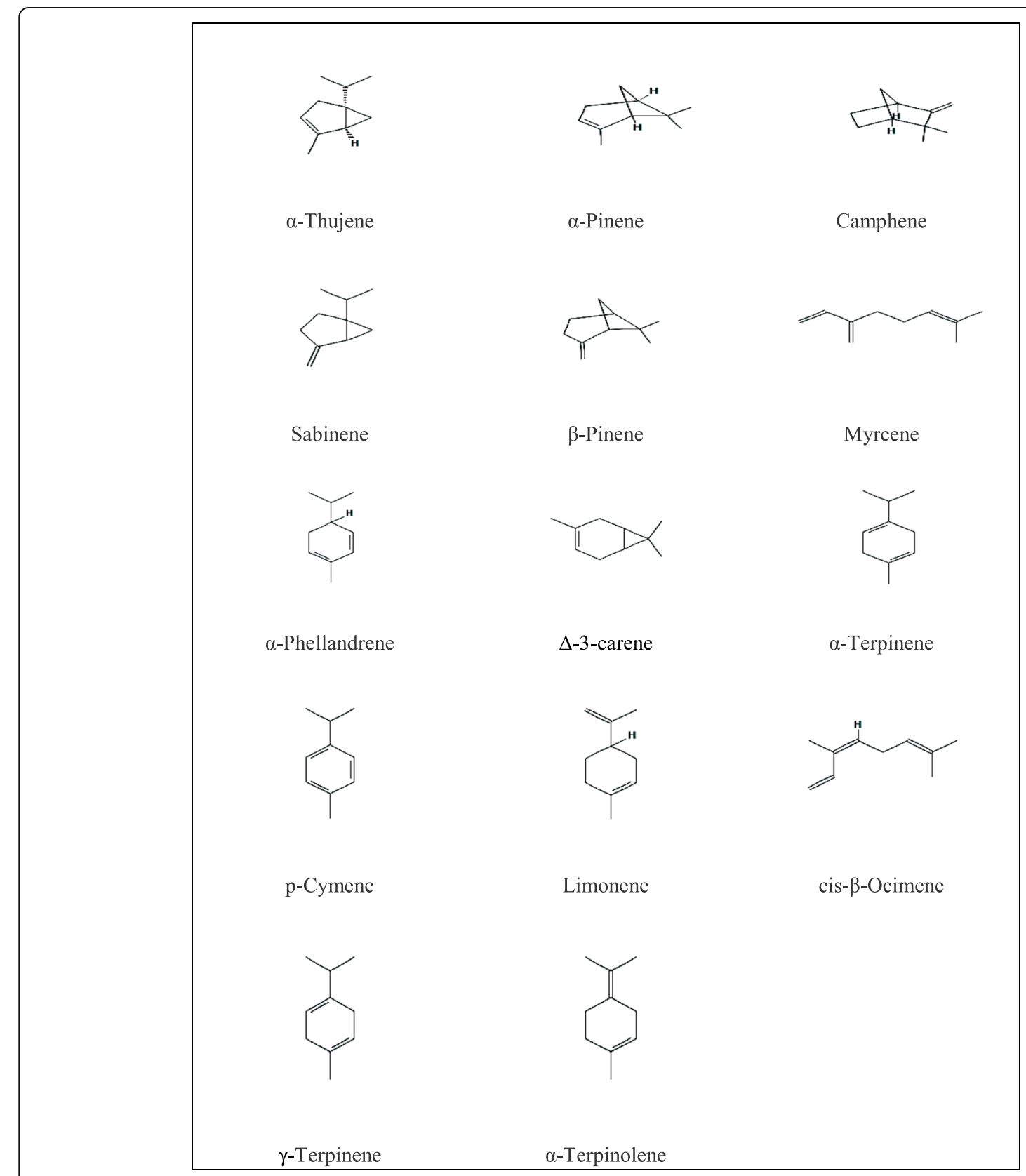

Fig. $1 \mathrm{MH}$ constituents 


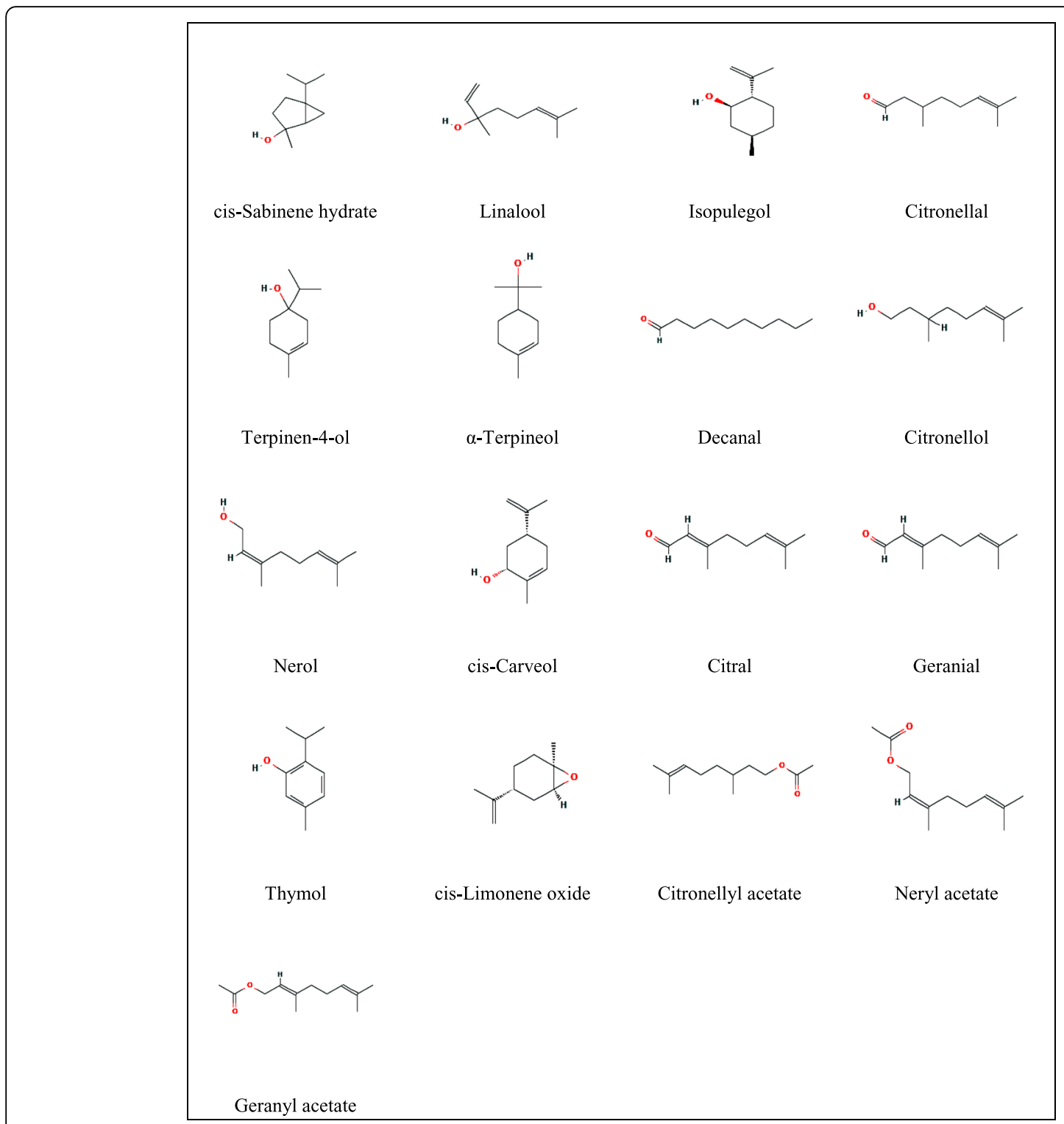

Fig. $2 \mathrm{OM}$ constituents

changes in the most detected components and chemical fractions are highly significant $(P<0.01)$ while $\alpha$ terpinolene, thymol, and $\alpha$-bisabolol are only significant $(P<0.05)$. Insignificant variations are observed in isopulegol, terpinen-4-ol, decanal, cis-carveol, citronellyl acetate, neryl acetate, germacrene D, and È,È-farnesol.

\section{Discussion}

In this study, various plant residues resulted in different variations of quantity and quality of sweet lemon EO. These changes might be due to the different variations in the metabolism and enzyme activities of EO formations in various plant residues (Burbott and Loomis 1969). The changes in EO composition with different plant residues were confirmed by previous investigators on some medicinal plants. Significant variations were reported in EO and its major constituents of oregano, thyme, and Eucalyptus sp. as a result of the difference of the plant part (Jordan et al. 2006; Kizil et al. 2008; Nejad-Ebrahimi et al. 2008; Omidbaigi et al. 2010; Ghasemi-Pirbalouti et al. 2011; Silva et al. 2011; Golparvar et al. 2015). The various fractions (aldehydes, aromatic components, $\mathrm{MH}, \mathrm{OM}$, $\mathrm{SH}$ OS, OD, and aliphatic hydrocarbons) of EO extracted from Sarcopoterium spinosum and Sodom apple plants were significantly changed with different plant organs (Sipahi et al. 2017; Wahba and Khalid 2018). On the other hand, the present study indicated 
<smiles>C=C1CCC/C=C\CC(C)(C)C1</smiles>

$\beta$-Humulene<smiles>C=C1CCC2=C(C)CC[C@H](C(C)C)[C@]23CCCC1=C3N</smiles>

Germacrene D<smiles>C=C1CCC=C2CC[C@H](C)[C@]12CC(C)(C)C</smiles>

$\alpha$-Caryophyllene<smiles>C=C(CCC=C(C)C)[C@H]1CC=C(C)CC1</smiles>

$\beta$-Bisabolene<smiles>C=C(C)C1CC[C@](C)(CC)[C@](C)(C(=C)C)C1</smiles>

$\beta$-Selinene

Fig. 3 SH constituents

that the EO of sweet lemon consists of various kinds of terpenes ( $\mathrm{MH}, \mathrm{OM}, \mathrm{SH}$, and $\mathrm{OS})$. Theses terpenes included natural flavor additives for food or fragrances in perfumery and in traditional and alternate medicines as aroma therapy (Brahmkshatriya and Brahmkshatriya 2013). Other important therapeutic uses of terpenoids include antimicrobial, antifungal, antiviral, antihyperglycemic, antiinflammatory, antioxidant, anticancer, antiparasitic, and immunomodulatory, and as a skin permeation enhancer (Brahmkshatriya and Brahmkshatriya 2013).

\section{Conclusion}

The compositions of EO isolated from sweet lemon residues were evaluated. The yields of peel EO were higher than those isolated from flowers and leaves. The leaf EO is rich with citronellal, limonene, and linalool. Flower EO is distinguished by high values of nerol, limonene, and $\beta$-nerolidol while peel EO is characterized by its high quantity of limonene. Various types of terpenes such as $\mathrm{MH}, \mathrm{OM}, \mathrm{SH}$, and $\mathrm{OS}$ were found in different EOs extracted from sweet lemon residues. This investigation indicated that sweet lemon residues contain<smiles>C=CC(C)(CCC=C(C)C)CCCC(C)=C(C)C</smiles>

$\beta$-Nerolidol

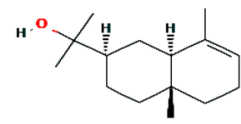

$\alpha$-Eudesmol

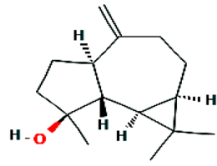

Spathulenol

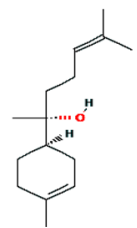

$\alpha$-Bisabolol<smiles>C=C1CC[C@]2(C)O[C@H]2CC[C@]2(C)C(C)(C)C[C@@]2(C)C1(C)C</smiles>

Caryophyllene oxide

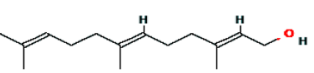

È,È-Farnesol

Fig. 4 OS constituents 
various effective substances that have different activities. Therefore, this study will lead to increase the natural sources of active substances, especially EOs.

\section{Abbreviations}

ANOVA: Analysis of variance; EO: Essential oil; GC: Gas chromatography; GC/ MS: Gas chromatography-mass spectrometry; HD: Hydrodistillation; MH: Monoterpene hydrocarbons; OM: Oxygenated monoterpenes; OS: Oxygenated sesquiterpenes; RI: Retention index according to DB5 column; SH: Sesquiterpenes hydrocarbons

\section{Acknowledgements}

The authors would like to thank the National Research Centre (NRC) for its facilities during this scientific work.

\section{Authors' contributions}

All authors have contributed significantly to the conception and design of the study, the interpretation of data, and the drafting and revision of the manuscript. All authors read and approved the final manuscript.

\section{Funding}

No specific fund was supplied for this work.

\section{Availability of data and materials}

The datasets supporting the results are included within the article.

\section{Ethics approval and consent to participate}

The manuscript does not contain studies involving human participants, human data, or human tissue.

\section{Consent for publication}

The authors declare that the work has consent for publication.

\section{Competing interests}

The authors declare that they have no competing interests.

\section{Author details}

${ }^{1}$ Medicinal and Aromatic Plants Department, National Research Centre, Dokki, Cairo, Egypt. 'Botany Department, National Research Centre, Dokki, Cairo, Egypt.

Received: 21 April 2019 Accepted: 12 September 2019

Published online: 26 October 2019

\section{References}

Adams RP (1995) Identification of essential oil components by gas chromatography/mass spectrometry. Allured Publ. Corp, Carol Stream

Brahmkshatriya PP, Brahmkshatriya PS (2013) Terpenes: chemistry, biological role, and therapeutic applications. In: Ramawat KG, Merillon JM (eds) Natural Products. Springer Heidelberg New York Dordrecht London

Burbott AJ, Loomis D (1969) Evidence for metabolic turnover monoterpene in peppermint. Plant Phys 44:173-179

Clevenger JF (1928) Apparatus for determination of essential oil. J Amer Pharm Asso 17:346-349

Davis PH (1982) Flora of Turkey and the East Aegean Islands, vol 7. University Press, Edinburgh, pp 349-382

Fisher K, Phillips CA (2006) The effect of lemon, orange and bergamot essential oils and their components on the survival of Campylobacter jejuni, Escherichia coli O157, Li steria monocytogenes, Bacillus cereus and Staphylococcus aureus in vitro and in food systems. J App Microbio 101:1232-1240

Foucart T (1982) Analyse Factorielle, Programmatiol Sur Micro- ordinateur. Masson ITCF, Paris

Ghasemi-Pirbalouti A, Rahimmalek M, Malekpoor F, Karimi A (2011) Variation in antibacterial activity, thymol and carvacrol contents of wild populations of Thymus daenensis subsp. daenensis Celak. Plant Om 4:209-214

Giwa SO, Muhammad M, Giwa A (2018) Utilizing of orange peels for essential oil production. ARPN J Eng App Sci 13(1):1-27

Golparvar AR, Mehrabi AM, Hadipanah A (2015) Effect of phonological stage on yield, essential oil, thymol percentage of Thymus daenensis Celak grown in Iran. Ind J Fund App Life Sci 5:2903-2910
Jordan MJ, Martınez RM, Cases MA, Sotomayor JA (2006) Seasonal variation of thymus hyemalis Lange and Spanish thymus vulgaris L. essential oils composition. Ind Crop Prod 24:253-263

Khursheed A, Rather MA, Rashid R (2016) Plant-based natural compounds and herbal extracts as promising apoptotic agents: their implications for cancer prevention and treatment. Adv Biomed Pharma 3:245-269

Kizil S, Ipek A, Arslan N, Khawar KM (2008) Effect of different developing stages on some agronomical characteristics and essential oil composition of oregano (Origanum onites). New Zealand J Crop Hort Sci 36:71-76

Krayni H, Zouari S, Chouaieb H, Fakhfakh N, Kossentini M, Zouar N (2015) Variations in the essential oil composition from different organs of Ruta chalepensis L. (Rutacea) growing wild in Tunisia. J Ess Oil Bear Plants 18:1495-1499

Nannapaneni R, Chalova VI, Crandall PG, Ricke SC, Johnson MG, Bryan CA (2009) Campylobacter and Arcobacter species sensitivity to commercial orange oil fractions. Int J Food Microbio 129:43-49

Nejad-Ebrahimi S, Hadian J, Mirjalili MH, Sonboli A (2008) Essential oil composition and antibacterial activity of Thymus caramanicusat different phenologycal stages. Food Chem 110:927-931

Omidbaigi R, Fattahi F, Karimzadeh GH (2010) Harvest time effect on the herb yield and essential oil content of lemon thyme (Thymus $\times$ citriodorus (Pers.) Schreb). Iran J Med Aro Plants 26:318-325

Pino JA, Sauri-Duch E, Cuevas-Glory L (2010) Volatile constituents of peel and leaf oils from Citrus limettioides Tan. J Ess Oil Bear Plant 13(3):292-296

Silva SM, Abe SY, Murakami FS, Frensch G, Marques FA, Nakashima T (2011) Essential oils from different plant parts of Eucalyptus cinerea F. Muell. ex Benth. (Myrtaceae) as a source of 1, 8-cineole and their bioactivities. Pharma 4:1535-1550

Sipahi H, Korkmaz B, Avsar C, Fandakli S, Elmas E (2017) Volatile profiles, antioxidant, and antimicrobial activities of essential oils and extracts of different parts from Sarcopoterium spinosum (L.) Spach growing wild in Sinop (Turkey). J Ess Oil Bear Plant 20:688-700

Snedecor GW, Cochran WG (1990) Statistical methods, 11th edn. lowa State Univ. Press, Ames lowa

Velázquez-Nuñez MJ, Avila-Sosa R, Palou E, López-Malo A (2013) Antifungal activity of orange (Citrus sinensis var. Valencia) peel essential oil applied by direct addition or vapor contact. Food Cont 31:1-4

Viuda-Martos M, Ruiz-Navajas Y, Fernández-López J, Pérez-Álvarez JA (2009) Chemical composition of mandarin (C. reticulata L.), grapefruit (C. paradisi L.), lemon (C. limon L.) and orange (C. sinensis L.) essential oils. J Ess Oil Bear Plants 12:236-243

Wahba HE, Khalid AK (2018) Comparative study on essential oil composition in various organs of Sodom apple (Calotropis procera) grown wild in Egypt. As $J$ Plant Sci 17(2):85-90

Yeung TK (1999) The mode of action of taxol: apoptosis at low concentration and necrosis at high concentration. Biochem Biophys Res Comm 263:398-404

\section{Publisher's Note}

Springer Nature remains neutral with regard to jurisdictional claims in published maps and institutional affiliations.

\section{Submit your manuscript to a SpringerOpen ${ }^{\circ}$ journal and benefit from:}

- Convenient online submission

- Rigorous peer review

- Open access: articles freely available online

- High visibility within the field

- Retaining the copyright to your article

Submit your next manuscript at $\boldsymbol{\nabla}$ springeropen.com 